\section{Congress moves to open up access for foreign academics}

\section{Washington}

Legislation currently moving through the US Congress would increase dramatically the number of high-technology workers allowed into the country. It would also set aside for the first time a number of visas for foreign-born faculty and graduate students, or do away altogether with restrictions on university hiring.

Congress has raised the numerical caps on so-called $\mathrm{H}-1 \mathrm{~B}$ visas in recent years (see Nature 400, 96; 1999). But demand, driven largely by the software industry, continues to outstrip the available number of slots, which is now set by law at 115,000 per year.

The cap has already been reached less than halfway through the current fiscal year, which runs until October. Because universities tend to hire in the spring, they are hardest hit when the H1-B visa slots run out early.

A Senate bill introduced in February by Orrin Hatch (Republican, Utah) and Spencer Abraham (Republican, Michigan) would raise the ceiling to $195,000 \mathrm{H1}-\mathrm{B}$ visas in each of the next three years. More importantly for the academic community, it would exempt university applicants from the caps. The bill was referred to the full Senate last week a after quick passage through the judiciary committee, which is chaired by Hatch.

In the House of Representatives, David Dreier (Republican, California) has taken a different approach, raising the number of H1-Bs to 200,000 for the next three years, and earmarking 10,000 of these for universities.

Lobbyists for the academic community would prefer the open-ended Senate version, but 10,000 visas "is probably reasonably close" to what universities need, according to Victor Johnson, Senior Director for Public Affairs at NAFSA, a Washington-based education association.

Last week Lamar Smith, the Texas Republican who chairs the House immigration subcommittee, introduced a third bill, which would remove the H1-B caps altogether. But the bill comes with strings attached, and has drawn fire from the computer industry.

Smith has consistently sought to protect American-born workers, and his bill would require that companies pay foreign $\mathrm{H} 1-\mathrm{B}$ workers no less than $\$ 40,000$ per year, and that they show that they have increased their number of American employees.

Johnson is optimistic that the special treatment for university workers will survive. "There is a will in Congress this year to try to get something passed that would give both the industry and the universities some relief," he says.

Tony Reichhardt

\title{
Women and ethnic minorities needed for US skills gap...
}

Washington

A projected shortage of science and technology workers could have a "devastating" effect on the US economy by 2050 unless it is addressed now, a report from the White House warned last week.

The report, published by President Bill Clinton's National Science and Technology Council, warns that two problems are on the horizon. First, the number of science and technology workers threatens to fall below that needed to keep the United States competitive - the demand for staff in some science sectors has already outstripped supply.

Second, demographic trends mean that the problem will be exacerbated if the underrepresentation of minorities and women in the science, technology and engineering (ST\&E) sector is not addressed. The Census Bureau projects that, between 1995 and 2050, non-whites will grow from 26 per cent of the US workforce to 48 per cent.

The implication is that the ST\&E workforce will shrink unless more women and minorities enter it. In 1997, for example, white men made up 36 per cent of the population, but 65 per cent of the ST\&E workforce.

"If current trends persist, our nation may begin to fall far short of the talent needed to spur the innovation process that has given America such a strong economy," said Neal Lane, President Clinton's science adviser, in a statement accompanying the report.

Lane also warned against the country's reliance on foreign workers to meet needs in

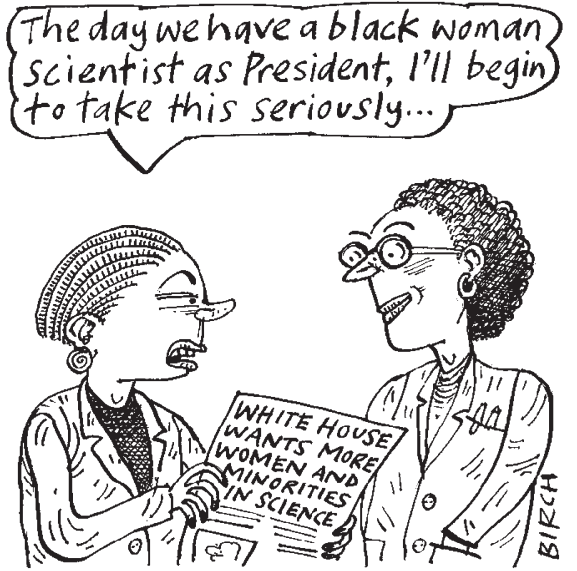

academia and high-technology (see left). "Our leadership in science and technology is largely due to this situation. But we cannot expect it to continue. We will have to do a much better job of growing our own talent."

The report calls for more research on the barriers that exclude women and minorities from science, and tells federal agencies to address these, for example through financial help for students.

The report, which was compiled by an inter-agency working group, is widely endorsed in Washington. But some point to a lack of clear recommendations. "It's not clear to me what they're asking agencies to do that they're not doing already," said one Capitol Hill aide who follows the issue. Meredith Wadman - www.whitehouse.gov/WH/EOP/OSTP/html/ workforcerpt.pdf

\section{... as academic pay fails to keep up}

\section{San Diego}

The salaries of faculty members at US universities have risen for the third straight year - but the rate of increase is slowing down. A survey of about 1,770 universities, released last week by the American Association of University Professors (AAUP), showed a 3.7 per cent increase in the average salary in 1999-2000, only half the previous year's increase when adjusted for inflation.

In 1985, other professionals were paid 13.8 per cent more than university teaching staff. By 1997 , says the AAUP, which has 45,000 members at US colleges and universities, this disparity had risen to 24 per cent.
Linda Bell, an economist at Haverford College in Pennsylvania, who conducted the AAUP survey, said that this trend bodes ill for the future. "Many of our best students will invariably turn away from the academic profession because they are unwilling to make the kind of financial sacrifice it requires," says Bell, currently on sabbatical at the University of California at San Diego.

Although the average salary has risen, there have been no increases at some universities. "Many professors, including myself, have not had a salary increase in a decade," says Henry Slucki, a behaviour analyst who is president of the AAUP chapter at the University of Southern California, Los Angeles.

The AAUP survey also highlighted the salary gap between women and men, which "has not narrowed in 10 to 15 years," says Bell. She notes that other professionals have seen the gap in pay shrink.

"The largest salary differences between men and women faculty occur in research universities, while the smallest occur in four-year colleges," the AAUP survey found. Overall, however, research universities pay 30 to 50 per cent more than other types of institutions. Rex Dalton http://www.aaup.org 